\title{
Fashion Design Students as "Thrift Mavens": An Interpretive Approach to How Fashion Design Students Can Influence Thrift Shopping
}

\author{
Kendra Lapolla and Jihyun "J." Kim \\ Kent State University, Kent, OH, USA
}

Keywords: Second-hand clothing, Marketing, Customer Service

In recent years thrift shopping for second-hand clothing has become more socially acceptable and is not limited only to low income clients (James 2011; Wodon \& Wodon, 2013). Thus with more diversity in thrift shoppers, motives for shopping are not solely based on financial constraint. For instance, thrift shoppers with higher incomes enjoy both thrift and hedonic benefits from thrift shopping (Bardhi \& Arnould, 2005). In order to satisfy this broader range of customers, thrift stores have a critical need to focus on their overall store image. In an effort to provide suggestions on how to improve store image, Mitchel and Montgomery (2010) examined thrift store competition and found thrift store customers most valued cleanliness of the store, organization of displays, cost to benefit ratio (value), friendliness of store staff, and quality of merchandise. Wodon and Wodon (2013) also identified customer service and quality of merchandise as drivers in thrift store shoppers' satisfaction and further stressed this importance when attracting new customers. However, customers' desire to shop thrift struggle with knowing where to find the best selection of products and thrift stores generally have minimal budgets for advertising (Christiansen \& Snepenger, 2005). To aid in these challenges, Christiansen and Snepenger (2005) identified the existence of a "thrift maven" as someone who encourages thrift shopping by passing on information of the thrift markets to other individuals. In this study, we explored any "thrift mavens" among fashion design students and their post purchase word-ofmouth behaviors regarding their thrift items and retailers.

Data for this study were collected using an interpretive approach through semi-structured personal interviews with ten female fashion design students attending a Midwestern university in the U.S. We selected participants for the interview based on the criteria that they have shopped at a second-hand clothing retailer at least once in the last six months. We specifically used a story telling technique (Curedale, 2013) during the interview to facilitate a more natural setting for participants to discuss anything on their minds. Participants were encouraged to bring their thrift items to the interview to talk about their story and/or experience regarding the items. Openended questions addressed what they had purchased, in-store experiences, and if they had ever influenced anyone else to shop at thrift stores. Both researchers were present at all ten interview sessions, which were digitally recorded for audio and downloaded for the transcribing. Items brought by participants were digitally photographed as well. For analysis of the verbatim, qualitative data, we used thematic coding and grouping techniques.

The findings in this study identified our participants, fashion design students, as potential "thrift mavens" that could advocate thrift shopping behavior by spreading positive word-ofmouth marketing to new customers, promoting selection and quality of merchandise, and 
contributing to customer service experiences such as upcycling and styling. We found a majority of fashion design students acted as "thrift mavens" by influencing those closest to them to shop at thrift stores. One participant says, "I've had friends who have said that they want to go with me. I've also had different friends from college who text me and ask where [the second-hand stores] are in this area." In some cases these participants also actively sought out thrift stores while travelling or when they moved to a new area. Their knowledge of apparel as fashion design students additionally helped them identify quality merchandise and unique garments. For example, the other participant states, "Like I know when I've got angora or silk in my hand or something nice." The finding is in line with Wodon and Wodon (2013) who also identified that one's knowledge of quality merchandise can be valuable in word-of-mouth marketing for thrift stores. Other participants noted potential to upcycle or alter garments from the thrift stores that might initially go unnoticed by other customers.

These findings have several implications for thrift stores, as well as those looking for second-hand clothing. By acting as "thrift mavens" fashion design students can encourage thrift shopping by sharing information about which thrift stores have quality merchandise to other potential thrift shoppers. These students could also provide advice to those running thrift stores to better visually organize merchandise and provide styling tips for garments otherwise overlooked. Also, fashion design students could offer to volunteer at thrift shops to help customers find unique and quality merchandise. As a similar example, Koh, Kuo, Lauterbach, Liebman and McVittie (2009) created a mobile and web-based system called TreasureHunter to help shoppers' request items that treasure hunters could find in local thrift stores. Additionally fashion design students could also help encourage thrift shopping by offering services to upcycle or alter garments in a creative way to update fashions for customers.

Bardhi, F., \& Arnould, E. J. (2005). Thrift shopping: Combining utilitarian thrift and hedonic treat benefits. Journal of Consumer Behaviour, 4(4), 223-233.

Christiansen, T., \& Snepenger, D. J, (2005). Information sources for thrift shopping: Is there a "thrift maven"? Journal of Consumer Marketing, 22(6), 323-331.

Curedale, R. (2013). Design thinking: Process and methods manual. Topanga, CA: Design College Community, Inc.

James, S. (2011), Adapting to hard times: Family participation patterns in local thrift economies. Family Relations, 59(4), 383-395.

Koh, S., Kuo, A., Lauterbach, D., Liebman, N., \& McVittie, A. (2009). TreasureHunter: A system to increase the reuse of local used goods. CHI 2009 - Student Design Competition. April 4-9, Boston, MA, USA. 2835-2840.

Mitchel, M., \& Montgomery, R. (2010). An examination of thrift store shoppers. The Marketing Management Journal, 20(2), 94-107.

Wodon, D., \& Wodon, N. (2013). What Drives Individual Sales at Nonprofit Thrift Stores? Economics Bulletin, 33(4), 2791-2800. 